\title{
PEMANFAATAN TEKNOLOGI INFORMASI DALAM PEMBENTUKAN KARAKTER PESERTA DIDIK
}

\author{
Ramadhani $^{4}$ \\ Surel: ramadhani085@gmail.com
}

\begin{abstract}
Abstrak
Pendidikan sangat berperan dalam peningkatan kualitas sumber daya manusia (SDM).SDM yang dimaksud tidak hanya terbatas pada pengetahuan dan keterampilan tetapi juga pada sikap atau karakter.Artikel ini bertujuan untuk mendeskripsikan pemanfaatan teknologi informasi dalam pembentukan karakter.Teknologi informasi diharapkan mampu menjadi salah satu media yang dapat dimanfaatkan pendidik dalam membangun karakter peserta didik. Teknologi informasi juga diharapkan mampu membantu pendidik dalam menyeleksi dan menyaring informasi yang akan disampaikan kepada peserta didik. Oleh karena itu kompetensi pendidik mengenai teknologi informasi juga diharapkan dapat selalu ditingkatkan. Pada akhirnya peserta didik diharapkan memiliki kemampuan secara aktif dalam memahami informasi yang ia dapatkan sehingga mampu bersikap kritis dalam memecahkan masalah pendidikan dan sosial yang dihadapi.
\end{abstract}

Kata kunci: teknologi, informasi, bersikap kritis, karakter.

\section{PENDAHULUAN}

Peradapan manusia telah berubah seiring dengan perkembangan teknologi, informasi dan komunikasi (TIK).Salah satunya adalah perubahan sosial budaya yang membawa dampak terhadap aspek kehidupan.Dampak tersebut berupa dampak negative dan positif.

Perkembangan teknologi dan informasi juga dapat dengan mudah membawa beragam unsur budaya asing masuk ke dalam kehidupan manusia. Unsur budaya asing tersebut membawa nilai-nilai baru yang terkadang bertentangan dengan nilai-nilai lama.Hal ini lah yang membuat bergesernya nilai-nilai karakter. Hal ini sesuai dengan pendapat Tilaar (2002, hlm. 63) yang mengungkapkan bahwa mengadopsi budaya global tanpa dasar yang kuat dari kebudayaan sendiri berarti manusia Indonesia akan kehilangan identitasnya

Hancurnya nilai-nilai dan moral dalam masyarakat yang ditandai dengan merebaknya berbagai kasus kekerasan, membutuhkan kelahiran baru pendidikan karakter di dalam sekolah.Mundurnya pendidikan karakter, membuat kita bertanya-tanya apakah masih ada relevansi pendidikan karakter dalam sekolah. Jika masih relevan lalu bagaimana cara kita menghidupkan kembali dan melalui kegiatan-kegiatan pendidikan apa kita dapat memberikan dan menananmkan pendidikan karakter dalam diri siswa.Rendahnya karakter bangsa telah di ungkapkan oleh Kemendiknas (2010, hlm. 2) yang mengakui bahwa telah terjadi dekadensi moral di kalangan pelajar dan mahasiswa.

Sekolah merupakan salah satu tempat yang efektif bagi pembentukan karakter seorang individu.Sejak dahulu, sekolah telah memiliki tujuan utama dalam bidang

Program Pascasarjana Universitas Negeri Medan 
pendidikan, yaitu membentuk manusia yang cerdas dan juga memiliki watak atau karakter yang baik.Untuk mencapai tujuan tersebut, sekolah memiliki tanggung jawab yang besar dalam pendidikan karakter bagi seluruh siswanya, terutama melalui disiplin, keteladanan dan organisasi sekolah (kebijakan dan kurikulum).

Lingkungan sekolah dapat menjadi tempat yang baik dalam menanamkan karakter siswa.Dengan demikian, harusnya segala kegiatan yang ada di sekolah, baik kegitan pembelajaran maupun kegitan pembiasaan-pembiasaan semestinya dapat diintegrasikan dalam program pendidikan karakter. Jadi, pendidikan karakter merupakan usaha bersama seluruh warga sekolah untuk mewujudkan dan menciptakan suatu kultur baru di sekolah, yaitu kultur pendidikan karakter. Penanaman dan pembiasaan pendidikan karakter di sekolah melalui lingkungan pendidikan dapat dilaksanakan secara langsung maupun secara tidak langsung dan akhirnya terbentuklah suatu kultur sekolah.

Generasi muda sebagai generasi penerus bangsa diharapkan dapat membentengi diri dalam menghadapi kemajuan teknologi informasi.Orang tua dan pendidik sangat berperan dalam hal ini.Pendidik bukan sekadar berperan mentransfer ilmu pengetahuan tetapi juga membangun karakter peserta didik.

Berdasarkan pemaparan di atas, rumusan masalah artikel ini adalah bagaimanakah pemanfaatan teknologi informasi dalam membangun karakter.Tujuan artikel ini adalah untuk mendeskripsikan manfaat teknologi informasi dalam membangun karakter.

\section{PEMBAHASAN}

\section{Pendidikan Karakter}

Karakter merupakan kepribadian seseorang yang terbentuk dari hasil internalisasi berbagai nilai-nilai yang diyakini dan digunakan sebagai landasan untuk berpikir dan bertindak. Hasan (2010:3) mengatakan bahwa karakter adalah watak, tabiat, akhlak, atau kepribadian seseorang yang terbentuk dari hasil internalisasi berbagai kebajikan yang diyakini dan digunakan sebagai landasan untuk cara pandang, berpikir, bersikap, dan bertindak. Definisi karakter tersebut dapat dipahami bahwa karakter merupakan manifestasi dari sifat-sifat yang disebut kebajikan.

Menurut Megawangi (Kesuma, 2011), pendidikan karakter adalah sebuah usaha sadar untuk mendidik anak-anak agar dapat mengambil keputusan dengan bijak dan mempraktikkannya dalam kehidupan sehari-hari sehingga mereka dapat memberikan kontribusi yang positif kepada lingkungan.

Jadi, pendidikan karakter merupakan usaha yang sungguh-sungguh untuk membantu orang memahami, peduli, dan bertindak berdasarkan nilai-nilai etika inti. Ketika kita berpikir tentang jenis karakter yang inginkan bagi anak-anak, jelas bahwa kita ingin mereka bisa menilai apa yang benar, peduli secara mendalam tentang apa yang benar, dan kemudian melakukan apa yang mereka yakini benar, bahkan dalam menghadapi tekanan dari luar dan godaan dari dalam.

Nilai-nilai yang dikembangkan dalam pendidikan karakter tersebut dirumuskan sebanyak 18 nilai karakter (Hasan, 2010:9ᄀ10). 
Religius, yaitu sikap dan perilaku yang patuh dalam melaksanakan ajaran agama yang dianutnya, toleran terhadap pelaksanaan ibadah agama lain, dan hidup rukun dengan pemeluk agama lain.

Jujur, yaitu perilaku yang didasarkan pada upaya menjadikan dirinya sebagai orang yang selalu dapat dipercaya dalam perkataan, tindakan, dan pekerjaan.

Toleransi, yaitu sikap dan tindakan yang menghargai perbedaan agama, suku, etnis, pendapat, sikap, dan tindakan orang lain yang berbeda dari dirinya.

Disiplin, yaitu tindakan yang menun-jukkan perilaku tertib dan patuh pada berbagai ketentuan dan peraturan.

Kerja keras, yaitu perilaku yang menunjukkan upaya sungguh-sungguh dalam mengatasi berbagai hambatan belajar dan tugas, serta menyelesaikan tugas dengan sebaik-baiknya.

Kreatif, yaitu berpikir dan melakukan sesuatu untuk menghasilkan cara atau hasil baru dari sesuatu yang telah dimiliki.

Mandiri, yaitu sikap dan perilaku yang tidak mudah tergantung pada orang lain dalam menyelesaikan tugas-tugas.

Demokratis, yaitu cara berfikir, bersikap, dan bertindak yang menilai sama hak dan kewajiban dirinya dan orang lain.

Rasa ingin tahu, yaitu sikap dan tindakan yang selalu berupaya untuk mengetahui lebih mendalam dan meluas dari sesuatu yang dipelajarinya, dilihat, dan didengar.

Semangat kebangsaan, yaitu cara berpikir, bertindak, dan berwawasan yang menempatkan kepentingan bangsa dan negara di atas kepentingan diri dan kelompok.

Cinta tanah air, yaitu cara berfikir, bersikap, dan berbuat yang menunjukkan kesetiaan, kepedulian, dan penghargaan yang tinggi terhadap bahasa, lingkungan fisik, sosial, budaya, ekonomi, dan po-litik bangsa.

Menghargai prestasi, yaitu sikap dan tin-dakan yang mendorong dirinya untuk menghasilkan sesuatu yang berguna bagi masyarakat, dan mengakui, serta menghormati keberhasilan orang lain.

Bersahabat/komunikatif, yaitu tindakan yang memperlihatkan rasa senang berbicara, bergaul, dan bekerja sama dengan orang lain.

Cinta damai, yaitu sikap, perkataan, dan tindakan yang menyebabkan orang lain merasa senang dan aman atas kehadiran dirinya.

Gemar membaca, yaitu kebiasaan menyediakan waktu untuk membaca berbagai bacaan yang memberikan kebajikan bagi dirinya.

Peduli lingkungan, yaitu sikap dan tin-dakan yang selalu berupaya mencegah kerusakan pada lingkungan alam di sekitarnya, dan mengembangkan upaya-upaya untuk memperbaiki kerusakan alam yang sudah terjadi.

Peduli sosial, yaitu sikap dan tindakan yang selalu ingin memberi bantuan pada orang lain dan masyarakat yang membutuhkan.

Tanggung jawab, yaitu sikap dan perilaku seseorang untuk melaksanakan tugas dan kewajibannya, yang seharusnya dia lakukan, terhadap diri sendiri, masyarakat, lingkungan (alam, sosial dan budaya), negara dan Tuhan Yang Maha Esa.

Lickona dalam Sudrajat (2011:49) menyatakan bahwa terdapat tujuh hal yang melatarbelakangi pentingnya pendidikan karakter seperti berikut. 
Cara terbaik untuk menjamin anak-anak (siswa) memiliki kepribadian yang baik dalam kehidupannya.

Cara untuk meningkatkan prestasi akademik.

Sebagian siswa tidak dapat membentuk karakter yang kuat bagi dirinya di tempat lain.

Persiapan siswa untuk menghormati pihak atau orang lain dan dapat hidup dalam masyarakat yang beragam.

Berangkat dari akar masalah yang ber-kaitan dengan problem moral-sosial, se-perti ketidaksopanan, ketidakjujuran, kekerasan, pelanggaran kegiatan seksual, dan etos kerja (belajar) yang rendah.

Persiapan terbaik untuk menyongsong perilaku di tempat kerja.

Pembelajaran nilai-nilai budaya yang me-rupakan bagian dari kerja peradaban.

Dewasa ini pendidikan menghasilkan banyak orang yang pandai, namun

bermasalah dengan hati nuraninya.Oleh karena itu, pengembangan jati diri atau karakter individu harus dibangun, dibentuk, dikembangkan, dan dimantapkan.Pengembangan karakter individu dapat menggunakan metode knowing the good, feeling the good, and acting the good.Knowing the good mudah diajarkan sebab pengetahuan bersifat kognitif saja. Setelah knowing the good harus ditumbuhkan feeling loving the good, yakni bagaimana merasakan dan mencintai kebajikan menjadi penggerak yang bisa membuat orang senantiasa mau berbuat suatu kebaikan, sehingga tumbuh kesadaran bahwa orang mau melakukan perilaku kebajikan karena cinta dengan perilaku kebajikan itu. Setelah terbiasa melakukan kebajikan, acting the good akan berubah menjadi kebiasaan. Melalui kebiasaan-kebiasaan yang baik akan muncul hasrat untuk berubah dalam diri seseorang. Selain itu, agar seseorang memiliki karakter mulia dibutuhkan upaya dan kerjasama dari berbagai pihak, yaitu antara orang tua, sekolah, dan masyarakat.

Pendidikan karakter bertujuan untuk meningkatkan mutu proses dan hasil pendidikan yang mengarah pada pembentukan karakter dan akhlak mulia peserta didik secara utuh, terpadu, dan seimbang sesuai dengan standar kompetensi lulusan pada se-tiap satuan pendidikan. Melalui pendidikan karakter peserta didik diharapkan mampu secara mandiri meningkatkan dan menggunakan pengetahuannya, mengkaji dan menginternalisasikan serta mempersonalisasikan nilai-nilai karakter dan akhlak mulia sehingga terwujud perilaku sehari-hari.

Hasan (2010:7) menjelaskan tujuan pendidikan karakter sebagai berikut.

Mengembangkan potensi kalbu / nurani / afektif peserta didik sebagai manusia dan warga negara yang memiliki nilai-nilai budaya dan karakter bangsa.

Mengembangkan kebiasaan dan perilaku peserta didik yang terpuji dan sejalan dengan nilai-nilai universal dan tradisi budaya bangsa yang religius.

Menanamkan jiwa kepemimpinan dan tanggung jawab peserta didik sebagai generasi penerus bangsa.

Mengembangkan kemampuan peserta didik menjadi manusia yang mandiri, kreatif, berwawasan kebangsaan.

Mengembangkan lingkungan kehidupan sekolah sebagai lingkungan belajar yang aman, jujur, penuh kreativitas dan persa-habatan, serta dengan rasa kebangsaan yang tinggi dan penuh kekuatan. 
Fungsi pendidikan karakter seperti menurut Fathurrohman dalam Mulyasa (2013:97) adalah sebagai berikut.

Pengembangan: pengembangan potensi peserta didik untuk menjadi perilaku yang baik bagi peserta didik yang telah memiliki sikap dan perilaku yang men-cerminkan karakter dan karakter bangsa.

Perbaikan: memperkuat kiprah pendi-dikan nasional yang bertanggung jawab dalam pengembangan potensi peserta didik yang lebih bermartabat.

Penyaring: untuk menyaring karakter-karakter bangsa sendiri dan karakter bangsa lain yang tidak sesuai dengan nilai-nilai karakter dan karakter bangsa.

Persoalan pentingnya watak atau karakter bukan hal baru. Ratna Megawangi (2010) mengutip Heraclitus (500S.M.) yang berkata bahwa "Character is destiny. It shapes the destiny of a whole society ". Untuk acuan konseptual tentang pendidikan, ada baiknya mempertimbangkan pengertian tentang pendidikan karakter yang juga dikutip oleh Ratna Megawangi (2010: 5) dari Bohlin, Farmer, dan Ryan (2001) sebagai berikut: "Character education is teaching students to know the good, love the good, and do the good. It is cognitive, emotional, and behavioral. It integrates head, heart, and hands. It places equal importance on all three ".

\section{Teknologi Informasi dan Komunikasi}

Teknologi informasi meliputi teknologi komputer (computing technology) dan teknologi komunikasi (communication technology) yang digunakan untuk memproses dan menyebarkan informasi baik itu yang bersifat finansial atau non finansial (Bodnar dan Hopwood, 1995). Sehingga dapat dikatakan bahwa Teknologi informasi adalahsegala cara atau alat yang yang terintegrasi yang digunakan untuk menjaring data, mengolah dan mengirimkan atau menyajikan secara elektronik menjadi informasi dalam berbagai format yang bermanfaat bagi pemakainya.

Istilah system informasi meliputi pemanfaatan teknologi informasi bagi para manajer.Thompson et al $(1991 ; 1994)$ mendefinisikan pemanfaatan teknologi sebagai manfaat yang diharapkan oleh pengguna sistem informasi dalam melaksanakan tugasnya dimana pengukurannya berdasarkan pada intensitas pemanfaatan, frekuensi pemanfaatan dan jumlah aplikasi atau perangkat lunak yang digunakan. Sedangkan Teddy Jurnali (2001) berpendapat bahwa pemanfaatan teknologi berhubungan dengan perilaku dalam menggunakan teknologi tersebut untuk melaksanakan tugasnya.

Perkembangan teknologi informasi dan komunikasi (TIK) telah memberikan pengaruh terhadap dunia pendidikan khususnya dalam proses pembelajaran. Menurut Rosenberg (2001:27), dengan berkembangnya penggunaan TIK ada lima pergeseran dalam proses pembelajaran yaitu:

Dari pelatihan ke penampilan.

Dari ruang kelas ke di mana dan kapan saja.

Dari kertas ke "on line" atau saluran.

Fasilitas fisik ke fasilitas jaringan kerja.

Dari waktu siklus ke waktu nyata.

Prinsip-prinsip Pemanfaatan TIK dalam Pembentukan Karakter Peserta Didik Menurut Madya (2011:1) pemanfaatan TIK tetap memberikan kontribusi signifikan terhadap : 
Pengembangan peserta didik menjadimanusia berkarakter danberkecerdasan intelektual

Pemberdayaan pendidik dan tenaga kependidikanterkait.

Hal tersebut hendaknya diterapkan prinsip-prinsip berikut:

Pemanfaatan TIK dalam pendidikan hendaknya mempertimbangkan

karaktersitik peserta didik, pendidik, dan tenaga kependidikan dalamkeseluruhan pembuatan keputusan TIK.

Pemanfaatan TIK hendaknya dirancang untuk memperkuat minat danmotivasi pengguna untuk menggunakannya semata guna meningkatkan dirinya, baik dari segi intelektual, spiritual (rohani), sosial, maupun ragawi.

Pemanfaatan TIK hendaknya menumbuhkan kesadaran dan keyakinan akanpentingnya kegiatan berinteraksilangsungdengan manusia (tatap muka), dengan lingkungan sosial-budaya (pertemuan, museum, tempat-tempat

bersejarah), dan lingkunganalam (penjelajahan) agar tetap mampu memelihara nilai-nilai sosial dan humaniora (seni dan budaya), dan kecintaan terhadap alam sebagai anugerah dari Tuhan Yang Maha Esa.

Pemanfaatan TIK hendaknya menjaga bahwa kelompok sasaran tetap dapat mengapresiasi teknologi komunikasi yang sederhana dan kegiatan-kegiatan pembelajaran tanpa TIK karena tuntutan penguasaan kompetensi terkaitdalam rangka mengembangkan seluruh potensi siswa secara seimbang.

Pemanfaatan TIK hendaknya mendorong pengguna untuk menjadi lebihkreatif dan inovatif sehingga tidak hanya puas menjadi konsumen informasiberbasis TIK.

Jika kerangka pikir dalam pemanfaatan TIK tersebut dapat diterapkan bersama prinsip-prinsip di atas, niscaya dampak positif akan dapat diperoleh secara optimal dan dampak negatifnya akan terkendali sampai titik minimal.

\section{SIMPULAN}

Pendidikan karakter merupakan usaha yang sungguh-sungguh untuk membantu orang memahami, peduli, dan bertindak berdasarkan nilai-nilai etika inti. Ketika kita berpikir tentang jenis karakter yang inginkan bagi anak-anak, jelas bahwa kita ingin mereka bisa menilai apa yang benar, peduli secara mendalam tentang apa yang benar, dan kemudian melakukan apa yang mereka yakini benar, bahkan dalam menghadapi tekanan dari luar dan godaan dari dalam.

Delapan belas nilai karakter yang harus dimiliki oleh peserta didik yaitu religious, jujur, toleransi, disiplin, kerja keras, kreatif, mandiri, demokratis, rasa ingin tahu, semangat kebangsaan, nasionalisme, cinta tanah air, menghargai prestasi, komunikatif, cinta damai, gemar membaca, peduli lingkungan, peduli social, dan tanggung jawab.

Teknologi informasi meliputi teknologi komputer (computing technology)

dan teknologi komunikasi (communication technology) yang digunakan untuk memproses dan menyebarkan informasi baik itu yang bersifat finansial atau non finansial.

Ada lima prinsip pemanfaatan TIK dalam pembentukan karakter peserta didik yaitu:

a. Pemanfaatan TIK mempertimbangakan peserta didik, pendidik, dan tenaga kependidikan. 
Pemanfataan TIK dirancang untuk memperkuat minat dan motivasi pengguna.

Pemanfaatan TIK hendaknyamenumbuhkan kesadaran dan keyakinan akanpentingnya kegiatan berinteraksi.

Pemanfaatan TIK hendaknya menjaga bahwa kelompok sasaran tetap dapat mengapresiasi teknologi komunikasi yang sederhana.

Pemanfaatan TIK hendaknya mendorong pengguna untuk menjadi lebihkreatif dan inovatif

\section{DAFTAR RUJUKAN}

Hasan, S. H., et al. 2010. Pengembangan Pendidikan Budaya dan Karakter Bangsa. Jakarta: Pusat Kurikulum, Badan Penelitian dan Pengembangan, Kementerian Pendidikan Nasional.

Kemendiknas.2010. Pengembangan Pendidikan Budaya dan Karakter Bangsa. Jakarta: Kemendiknas.

Kesuma, Dharma, dkk. 2011. Pendidikan Karakter Kajian Teori dan Praktik di Sekolah. Bandung: PT Remaja Rosda Karya.

Ratna Megawangi (2010).Strategi dan Implementasi Pendidikan Karakter di PAUD.Makalah disajikan dalam seminar tentang PAUD. Bogor.

Sudrajat, A. 2011. "Mengapa Pendidikan Karakter". Jurnal Pendidikan Karakter. Nomor I Tahun 2011, hlm. 47-58.

Suwarsih Madya. Optimalisasi Pemanfaatkan TIK untuk Meningkatkan Mutu Hakiki Pendidikan, makalah,Seminar Nasional,Milad UADXXX, 5 Febr 11

Teddy Jurnali. (2001). Analisis Pengaruh Faktor Kesesuaian Tugas-Teknologi dan Pemanfaatan Teknologi Informasi Terhadap Kinerja Akuntan Publik. Simposium Nasional Akuntansi IV. 2001

Thompson Ronald, Christoper A and Howell Jane. 1991. Personal Computing : Toward a Conceptual Model of Utilization. MIS Quarterly. March 1991

Tilaar H.A.R 2002.Pendidikan, Kebudayaan, dan Masyarakat Madani Indonesia. Bandung: Rosdakarya. 
